\title{
Analisis Pengaruh Pertumbuhan Perusahaan Terhadap Nilai Perusahaan Pada Perusahaan Gowa Motor Group Yang Terdaftar Di Bosowa Automotive
}

\section{Analysis Of The Influence Of Company Growth On Corporate Value In Gowa Motor Group Companies Listed In Bosowa Automotive}

\author{
${ }^{1}$ Ramli Toalib, ${ }^{2}$ Ady Kurnia \\ Fakultas Ekonomi, Universtas Indonesia Timur \\ (ramli_toalib@yahoo.co.id)
}

\begin{abstract}
Abstrak
Penelitian ini bertujuan untuk mengetahui pengaruh pertumbuhan perusahaan terhadap nilai perusahaan pada perusahaan Gowa Motor Group yang terdaftar di Bosowa automotive. Variabel independen dalam penelitian ini adalah pertumbuhan perusahaan, variabel dependennya adalah nilai perusahaan. Populasi penelitian ini adalah perusahaan Gowa Motor Group yang terdaftar di Bosowa automotive pada tahun penelitian 2014 sampai dengan 2017. Metode penentuan sampel dengan metode purposive sampling, dengan beberapa kriteria yang telah ditentukan maka jumlah sampel adalah sebanyak 4 perusahaan. Metode analisis data yang digunakan adalah regresi linier berganda dengan tingkat signifikasi 0,05 . Berdasarkan hasil analisis data dengan menggunakan uji parsial (uji-t) variabel Pertumbuhan perusahaan berpengaruh positif signifikan terhadap nilai perusahaan dengan nilai signifikansi 0,003 . Hasil uji ketepatan model diperoleh nilai $F_{\text {hitung }}$ sebesar 17,728 dengan nilai signifikansi sebesar 0,000. Analisis regresi menghasilkan Adjusted R sebesar 0,770 atau 77,0\%. Penelitian ini berarti variabel nilai perusahaan dapat dijelaskan oleh variabel pertumbuhan perusahaan, sebesar $77,0 \%$, sedangkan sisanya $23,0 \%$ dijelaskan oleh variabel lain di luar model.
\end{abstract}

Kata kunci: Nilai perusahaan, Pertumbuhan perusahaan, Return On Equity (ROE)

Abstract
This study aims to determine the effect of company growth on firm value in Gowa Motor Group companies registered with Bosowa automotive. The independent variable in this study is company growth, the dependent variable is the value of the company. The population of this study is the Gowa Motor Group company registered in Bosowa automotive in the 2014 to 2017. research methods of determining the sample using the purposive sampling method, with several predetermined criteria, the number of samples was 4 companies. The data analysis method used is multiple linear regression with a significance level of 0.05. Based on the results of data analysis using partial test ( $t$-test) the variable company growth has a significant positive effect on firm value with a significance value of 0.003. The results of the accuracy test of the model obtained a calculated $F$ value of 17.728 with a significance value of 0,000. Regression analysis produces Adjusted $R$ of 0.770 or 77.0\%. This study means that the firm's value variable can be explained by the company's growth variable, at $77.0 \%$, while the remaining $23.0 \%$ is explained by other variables outside the model.

Keywords: Company Value, Company Growth, Return On Equity (ROE)

\section{PENDAHULUAN}

Kondisi perekonomian yang semakin tidak menentu membuat banyak perusahaan mengalami masalah pendanaan dalam membiayai kegiatan operasionalnya. Masalah pendanaan merujuk pada permodalan dimana modal adalah hak sisa (residual interest) atas aktiva suatu entitas setelah dikurangi dengan hutang. Permodalan dibutuhkan baik ketika pendirian, pada saat perusahaan berjalan normal, maupun saat perusahaan 
mengadakan perluasan usaha (Hilmi, 2010). Sumber pendanaan dapat berasal dari pendanaan sendiri oleh pemilik ataupun berasal dari pihak eksternal yang berupa hutang. Hal ini dilakukan untuk memperoleh laba yang menjadi tujuan awal pendirian sebuah perusahaan.

Perusahaan yang akan go public bertujuan untuk meningkatkan kemakmuran pemilik atau para pemegang saham melalui peningkatan nilai perusahaan (Salvatore, 2005). Nilai perusahaan sangat penting karena dengan nilai perusahaan yang tinggi akan diikuti oleh tingginya kemakmuran pemegang saham (Brigham and Gapensi, 1996). Semakin tinggi harga saham semakin tinggi nilai perusahaan. Nilai perusahaan yang tinggi menjadi keinginan para pemilik perusahaan, sebab dengan nilai yang tinggi menunjukan kemakmuran pemegang saham juga tinggi. Kekayaan pemegang saham dan perusahaan dipresentasikan oleh harga pasar dari saham yang merupakan cerminan dari keputusan investasi, pendanaan (financing), dan manajemen asset.

Perusahaan mempunyai tujuan jangka panjang yaitu memaksimumkan nilai perusahaan. Semakin tinggi nilai perusahaan maka kemakmuran pemegang saham akan semakin meningkat. Menurut Aries (2011) nilai perusahaan merupakan hasil kerja manajemen dari beberapa dimensi diantaranya adalah arus kas bersih dari keputusan investasi, pertumbuhan dan biaya modal perusahaan. Bagi investor, nilai perusahaan merupakan konsep penting karena nilai perusahaan merupakan indikator bagaimana pasar menilai perusahaan secara keseluruhanApabila nilai perusahaan yang tersirat tidak baik maka investor akan menilai perusahaan dengan nilai rendah. Nilai perusahaan yang telah go public dapat dilihat dari harga saham yang dikeluarkan oleh perusahaan tersebut (Suharli, 2006).

Nilai perusahaan dapat pula dipengaruhi oleh besar kecilnya profitabilitas yang dihasilkan oleh perusahaan. Weston dan Copeland (1997) mendefinisikan probabilitas sejauh mana perusahaan menghasilkan laba dari penjualan dan investasi perusahaan. Apabila profitabitas perusahaan baik, maka para stakeholders yang terdiri dari kreditur, supplier, dan juga investor akan melihat sejauh mana perusahaan dapat menghasilkan laba dari penjualan dan investasi perusahaan. Dengan baiknya kinerja perusahaan akan meningkatkan pula nilai perusahaan (Suharli,2006). Profitabilitas adalah rasio dari efektifitas manajemen berdasarkan hasil pengembalian yang dihasilkan dari penjualan dan investasi.

Return on equity (ROE) merupakan rasio yang menunjukkan kemampuan perusahaan dalam menghasilkan laba bersih untuk pengembalian ekuitas pemegang saham. ROE merupakan rasio keuangan yang digunakan untuk mengukur profitabilitas dari ekuitas.Semakin besar hasil ROE maka kinerja perusahaan semakin baik. ROE menunjukkan keuntungan yang akan dinikmati oleh pemilik saham. Adanya pertumbuhan ROE menunjukkan prospek perusahaan yang semakin baik karena berarti adanya potensi peningkatan keuntungan yang diperoleh perusahaan. Apabila terdapat kenaikkan permintaan saham suatu perusahaan, maka akan menaikkan harga saham tersebut di pasar modal. Penelitian yang dilakukan oleh Mardiyati U, dkk (2012) serta Mahatma Dewi AS dan Wirajaya A (2013) menunjukkan adanya pengaruh ROE terhadap nilai perusahaan (PBV).

Berdasarkan hasil penelitian terdahulu faktor-faktor yang memengaruhi nilai perusahaan masih banyak yang belum menunjukkan kekonsistenan dan mengacu pada penelitian tersebut maka penulis tertarik untuk meneliti lebih lanjut dengan variabel independen pertumbuhan perusahaan untuk mengkaji ulang temuan dari Watts dan Zimmerman (1985). Data empiris yang diperoleh calon peneliti di Gowa Motor Group di Bosowa automotive 
yaitu nilai keuntungan bersih perusahaan dari tahun 2014 sampai dengan tahun 2017

yaitu :

Tabel 1. Daftar Net Profit Gowa Motor Group

\begin{tabular}{cccc}
\hline NO & TAHUN & NET PROFIT & KET \\
\hline 1 & 2014 & 1.066 .891 .591 & \\
\hline 2 & 2015 & 1.266 .411 .459 & \\
\hline 3 & 2016 & 332.059 .871 \\
\hline 4 & 2017 & 693.370 .342 \\
\hline
\end{tabular}

\section{METODE PENELITIAN}

Penelitian ini menggunakan pendekatan kuantitatif. Penelitian ini bertujuan untuk mencari pengaruh variabel tertentu terhadap variabel lainnya. Berdasarkan tingkat penjelasan dari kedudukan variabelnya maka penelitian ini bersifat asosiatif kausal, yaitu penelitian yang mencari hubungan sebab akibat, yaitu variabel independen/variabel yang memengaruhi (X) terhadap variabel dependen variabel yang dipengaruhi (Y) (Sugiyono, 2009:56). Dalam penelitian ini variabel dependen (terikat) adalah nilai perusahaan, sedangkan variabel independen (bebas) adalah pertumbuhan perusahaan.Penelitian ini dilakukan di Perusahaan Gowa Motor Group terdaftar di Bosowa Automotive. Data yang digunakan yaitu laporan keuangan perusahaan periode 2014-2017. Data diambil langsung dari perusahaan. Sedangkan waktu penelitian dilaksanakan pada bulan Januari 2020.

Populasi dalam penelitian ini adalah seluruh perusahaan Gowa Motor Group yang terdaftar di Bosowa Automotif dalam periode 2014-2017. Teknik yang digunakan dalam pengambilan sampel menggunakan metode purposive sampling yaitu metode penentuan sampel dengan pertimbangan tertentu (Sugiyono, 2009:116) dengan menggunakan karakteristik sebagai berikut :

a. Perusahaan Gowa Motor Group yang terdaftar di Bosowa Automotif dalam periode 2014-2017.

b. Perusahaan yang menerbitkan laporan keuangannya untuk periode yang berakhir pada 31 Desember, selama periode pengamatan.

c. Ketersediaan dan kelengkapan data selama penelitian. Apabila dalam proses penelitian terdapat perusahaan yang tidak dapat dihitung rasionya, maka akan dikeluarkan.

Jenis data yang digunakan dalam penelitian ini adalah data kuantitatif. ini merupakan data sekunder, yaitu data yang tidak secara langsung diberikan kepada pengumpul data yaitu laporan keuangan perusahaan Gowa Motor Group yang terdaftar di Bosowa Automotif dalam periode 2014-2017.Teknik pengumpulan data yang digunakan dalam penelitian ini yaitu dengan metode dokumentasi. Penelitian ini menggunakan teknik analisis regresi linier berganda karena variabel independen dalam penelitian satu.

\section{HASIL DAN PEMBAHASAN}

Tabel 2. Daftar Sampel Perusahaan Gowa Motor Group yang Terdaftar di Bosowa Autmotive Periode 2014-2017

\begin{tabular}{crrcc}
\hline NO & NAMA & PERUSAHAAN & KODE & KET \\
\hline 1 & PT. GOWA KENCANA MOTOR & GKM & \\
\hline
\end{tabular}




\begin{tabular}{lll}
\hline 2 & PT. GOWA DINASTI MOTOR & GDM \\
\hline 3 & PT. GOWA ISTANA MOTOR & GIM \\
\hline 4 & PT. PRO SADIRA EDAR MAKASSAR & PSEM \\
\hline
\end{tabular}

Sumber data : Diolah

Tabel 3. Daftar Hasil Perhitungan Nilai Perusahaan (Price to Book Value /PBV)

\begin{tabular}{|c|c|c|c|c|c|c|c|c|}
\hline \multirow{3}{*}{ No } & \multirow{3}{*}{ Kode } & \multirow{3}{*}{ Tahun } & \multirow{3}{*}{ Total Ekuitas } & $\begin{array}{l}\text { Jumlah } \\
\text { Saham }\end{array}$ & Harga Saham & \multirow{3}{*}{$\begin{array}{l}\text { Nilai } \\
\text { Buku }\end{array}$} & \multirow{3}{*}{ PBV } & \multirow{3}{*}{ KET } \\
\hline & & & & Beredar & (Rp/lembar) & & & \\
\hline & & & & \multicolumn{2}{|l|}{ (lembar) } & & & \\
\hline 1 & GKM & 2014 & 1.024 .271 .621 & 750 & 1.000 .000 & 1.365 .695 & 0,73 & \\
\hline 2 & GKM & 2015 & 1.019 .798 .493 & 750 & 1.000 .000 & 1.359 .731 & 0,74 & \\
\hline 3 & GKM & 2016 & 1.109 .279 .473 & 750 & 1.000 .000 & 1.479 .039 & 0,68 & \\
\hline 4 & GKM & 2017 & 976.998 .855 & 750 & 1.000 .000 & 1.302 .665 & 0,77 & \\
\hline 5 & GDM & 2014 & 13.378.138.049 & 12.500 & 1.000 .000 & 1.070 .251 & 0,93 & \\
\hline 6 & GDM & 2015 & 13.743 .692 .138 & 12.500 & 1.000 .000 & 1.099 .495 & 0,91 & \\
\hline 7 & GDM & 2016 & 13.988 .783 .646 & 12.500 & 1.000 .000 & 1.119 .103 & 0,89 & \\
\hline 8 & GDM & 2017 & 15.101 .763 .162 & 12.500 & 1.000 .000 & 1.208 .141 & 0,83 & \\
\hline 9 & GIM & 2014 & 1.000 .000 .000 & 1.000 & 1.000 .000 & 1.000 .000 & 1,00 & \\
\hline 10 & GIM & 2015 & 1.000 .000 .000 & 1.000 & 1.000 .000 & 1.000 .000 & 1,00 & \\
\hline 11 & GIM & 2016 & 1.040 .731 .806 & 1.000 & 1.000 .000 & 1.040 .732 & 0,96 & \\
\hline 12 & GIM & 2017 & 1.364 .396 .744 & 1.000 & 1.000 .000 & 1.364 .397 & 0,73 & \\
\hline 13 & PSEM & 2014 & 2.656 .058 .809 & 2.500 & 1.000 .000 & 1.062 .424 & 0,94 & \\
\hline 14 & PSEM & 2015 & 2.756 .453 .690 & 2.500 & 1.000 .000 & 1.102 .581 & 0,91 & \\
\hline 15 & PSEM & 2016 & 3.030 .712 .463 & 2.500 & 1.000 .000 & 1.212 .285 & 0,82 & \\
\hline 16 & PSEM & 2017 & 3.350 .584 .493 & 2.500 & 1.000 .000 & 1.340 .234 & 0,75 & \\
\hline
\end{tabular}

Sesuai tabel di atas dapat disimpukan bahwa besarnya nilai Price to Book Value minimum besarnya 0,79 dan nilai maksimum sebesar 0,96 . Nilai ratarata/mean sebesar 0,85 . Dengan standar deviasi 0,107 : Perusahaan yang mempunyai nilai Price to Book Value terendah adalah perusahaan PT Gowa Tabel 4. Daftar hasil Perhitungan Pertumbuhan Perusahaan (Growth)

\begin{tabular}{ccccccc}
\hline \multirow{2}{*}{ NO. } & \multirow{2}{*}{ KODE } & \multirow{2}{*}{ TAHUN } & \multirow{2}{*}{ Total asset $(\mathbf{t})$} & Total asset $(\mathbf{t}-1)$ & Growth & \multirow{2}{*}{ KET } \\
\cline { 4 - 5 } 1 & \multirow{2}{*}{ GKM } & \multirow{2}{*}{2014} & $(\mathbf{R p})$ & $(\mathbf{R p})$ & $(\boldsymbol{\%})$ & \\
\hline
\end{tabular}

Kencana Motor (GKM) pada tahun 2014 yaitu sebesar 0,79. Perusahaan yang mempunyai nilai Price to Book Value tertinggi yaitu perusahaan PT Gowa Istana Motor (GIM) pada tahun 2016 sebesar 0,96

Perhitungan Growth Sampel Penelitian Periode 2011-2014

Tabel 4. Daftar hasil Peritungan Pertumbuhan Perusahaan (Growth) 


\begin{tabular}{cccccc}
\hline 2 & GKM & 2015 & 19.318 .953 .193 & 19.008 .766 .643 & 1,63 \\
\hline 3 & GKM & 2016 & 21.558 .150 .835 & 19.318 .953 .193 & 11,59 \\
\hline 4 & GKM & 2017 & 22.526 .180 .951 & 21.558 .150 .835 & 4,49 \\
\hline 5 & GDM & 2014 & 23.395 .378 .715 & 23.078 .767 .112 & 1,37 \\
\hline 6 & GDM & 2015 & 23.839 .573 .726 & 23.395 .378 .715 & 1,90 \\
\hline 7 & GDM & 2016 & 24.856 .984 .413 & 23.839 .573 .726 & 4,27 \\
\hline 8 & GDM & 2017 & 26.396 .205 .762 & 24.856 .984 .413 & 6,19 \\
\hline 9 & GIM & 2014 & 1.000 .000 .000 & 1.000 .000 .000 & - \\
\hline 10 & GIM & 2015 & 1.000 .000 .000 & 1.000 .000 .000 & - \\
\hline 11 & GIM & 2016 & 11.518 .927 .561 & 1.000 .000 .000 & - \\
\hline 12 & GIM & 2017 & 13.644 .285 .349 & 11.518 .927 .561 & 18,45 \\
\hline 13 & PSEM & 2014 & 8.373 .806 .536 & 8.151 .798 .525 & 2,72 \\
\hline 14 & PSEM & 2015 & 8.580 .107 .258 & 8.373 .806 .536 & 2,46 \\
\hline 15 & PSEM & 2016 & 8.708 .278 .010 & 8.580 .107 .258 & 1,49 \\
\hline 16 & PSEM & 2017 & 10.520 .276 .027 & 8.708 .278 .010 & 20,81 \\
\hline
\end{tabular}

Sumber data : diolah

Sesuai tabel di atas dapat nilai minimum

Uji F atau uji Fisher dilakukan untuk Growth sebesar 1,37 dan nilai maksimum 20,81. Nilai rata-rata/mean sebesar 4,94. Dengan standar deviasi 6,431. Perusahaan yang mempuyai nilai Growth terendah adalah perusahaan PT Gowa Dinasty Motor (GDM) pada tahun 2014 sebesar 1,37. Perusahaan yang mempunyai nilai Growth tertinggi yaitu perusahaan PT Pro Sadira Edar Makassar (PESM) pada tahun 2016 sebesar 20,81.

\section{Hasil Pengujian}

Pengujian secara Simultan (uji F)

Tabel 7. Hasil Analisis Regresi Linier Berganda untuk uji F

ANOVA

\begin{tabular}{ccccccc}
\hline Model & $\begin{array}{c}\text { Sum Of } \\
\text { Squares }\end{array}$ & df & $\begin{array}{c}\text { Mean } \\
\text { Squares }\end{array}$ & F & Sig. \\
\hline 1 Regression & .137 & 3 & & 046 & 17.728 & $000^{\mathrm{a}}$ \\
\hline
\end{tabular}




\begin{tabular}{llll}
\hline Residual & .031 & 12 & .003 \\
Total & .168 & 15 & \\
& & & \\
\hline
\end{tabular}

\begin{tabular}{|c|c|c|c|}
\hline \multirow{6}{*}{ H01 } & \multicolumn{3}{|c|}{ Sumber data : diolah } \\
\hline & $: \beta 1,=0$ & berarti tidak terdapat & terhadap nilai perusahaan, sehingga $\mathrm{H} 01$ \\
\hline & & pengaruh & ditolak dan Ha1 diterima. \\
\hline & & DER, Growth, dan & Koefisien Determinasi (Adjusted R) \\
\hline & & Size secara simultan & Hasil uji adjusted $R$ dalam model \\
\hline & & terhadap Y & summary di atas diperoleh nilai adjusted $R$ \\
\hline \multirow[t]{4}{*}{ Ha1 } & $: \beta 1, \neq 0$ & berarti & sebesar 0,770 atau $77,0 \%$. Nilai $77,0 \%$ \\
\hline & & pengaruh & menunjukkan bahwa persentase \\
\hline & & DER, Growth, dan & sumbangan pengaruh \\
\hline & & $\begin{array}{l}\text { Size secara simultan } \\
\text { terhadap Y }\end{array}$ & $\begin{array}{l}\text { yaitu DER, Growth, Size terhadap variabel } \\
\text { dependen yaitu nilai perusahaan (PBV) }\end{array}$ \\
\hline \multirow{2}{*}{\multicolumn{3}{|c|}{$\begin{array}{r}\text { Berdasarkan tabel } 12 \text { diperoleh } \\
\text { nilai } \mathrm{F} \text { hitung sebesar } 17,728 \text { dengan nilai }\end{array}$}} & adalah sebesar $77,0 \%$. Dengan kata lain, \\
\hline & & & variasi variabel independen yang \\
\hline \multicolumn{3}{|c|}{ signifikansi $\quad$ sebesar $\quad 0,000 . \quad$ Nilai } & digunakan dalam model \\
\hline \multicolumn{3}{|c|}{$\begin{array}{l}\text { signifikansi yang dihasilkan tersebut lebih } \\
\text { kecil dari } 0,05(\mathrm{p}<0,05) \text {, sehingga }\end{array}$} & menjelaskan sebesar $77,0 \%$ variasi \\
\hline \multicolumn{3}{|c|}{ menunjukkan bahwa secara simultan } & $\begin{array}{l}\text { variabel dependen, sedangkan sisanya } \\
\text { sebesar } 23,0 \% \text { dipengaruhi atau dijelaskan }\end{array}$ \\
\hline \multirow{2}{*}{\multicolumn{3}{|c|}{$\begin{array}{l}\text { variabel DER, Growth dan Size } \\
\text { berpengaruh terhadap nilai perusahaan, }\end{array}$}} & oleh variabel lain yang tidak dimasukkan \\
\hline & & & \\
\hline
\end{tabular}
sehingga $\mathrm{H} 0$ ditolak dan Ha diterima.

Pengujian secara Parsial (uji t)

Uji $t$ merupakan pengujian yang dilakukan untuk mengetahui pengaruh secara individu variabel independen dalam penelitian terhadap variabel dependen. Apabila nilai signifikansi lebih kecil dari $0,05$ ( $\mathrm{p}<0,05)$, maka dapat disimpulkan bahwa variabel independen secara parsial berpengaruh signifikan terhadap variabel dependen:

Pertumbuhan Perusahaan/Growth
H01 : $\beta 1<0$, artinya tidak terdapat pengaruh positif Growth terhadap nilai perusahaan.
Ha1 : $\beta 1>0$,artinya terdapat pengaruh positif Growth terhadap nilai perusahaan.

Dari hasil uji $t$ untuk variabel Growth diperoleh nilai koefisien regresi 3,799 dan nilai signifikansi sebesar 0,003 . Nilai signifikansi tersebut lebih kecil dari nilai toleransi kesalahan yaitu $=0,05$. Oleh karena nilai koefisien bernilai negatif dan nilai signifikansi lebih kecil dari 0,05 maka variabel Growth berpengaruh positif

\section{PEMBAHASAN}

Dari hasil pengolahan data menyatakan bahwa pertumbuhan perusahaan yang diteliti memiliki rata-rata sebesar 4,94 dengan nilai minimum 1,37 dan nilai maksimum 20,81. Sedangkan standard deviation pertumbuhan perusahaan pada penelitian ini adalah sebesar 6,431 hasil tersebut menunjukkan bahwa nilai standar devisiasinya lebih besar daripada rata-rata pertumbuhan perusahaan yang menunjukkan bahwa data variabel pertumbuhan perusahaan mengindikasikan hasil yang kurang baik, hal tersebut dikarenakan standard deviation yang mencerminkan penyimpangan dari data variabel tersebut cukup tinggi karena lebih besar daripada nilai rata-ratanya. Hasil analisis statistik untuk variabel pertumbuhan perusahaan menunjukkan bahwa nilai koefisien regresi pertumbuhan perusahaan bernilai negatif sebesar -3,799. Dari hasil uji t untuk variabel pertumbuhan perusahaan diperoleh nilai signifikansi sebesar 0,003. Oleh karena nilai koefisien negatif dan nilai signifikansi lebih kecil dari 0,05, 
maka variabel pertumbuhan perusahan berpengaruh positif signifikan terhadap nilai perusahaan. Hasil penelitian ini sama dengan hasil penelitian yang dilakukan oleh Subekti (2001) yang menyatakan bahwa pertumbuhan perusahaan positif berpengaruh terhadap nilai perusahaan.

Dari sudut pandang investor, pertumbuhan suatu perusahaan merupakan tanda perusahaan memiliki aspek yang menguntungkan, dan investor pun akan mengharapkan tingkat pengembalian (rate of return) dari investasi yang dilakukan menunjukkan perkembangan yang baik. Hasil temuan ini membuktikan bahwa pengaruh pertumbuhan perusahaan terhadap nilai perusahaan berpengaruh negatif dan tidak signifikan Pertumbuhan yang tinggi menyebabkan kebutuhan dana meningkat. Para investor lebih percaya kepada perusahaan yang sudah mapan dan tidak sedang bertumbuh. Oleh karena itu walaupun tingkat pertumbuhan perusahaan tinggi, tidak akan memengaruhi kepercayaan investor sehingga tidak akan pula memengaruhi tingkat PBV perusahaan.

\section{KESIMPULAN DAN SARAN}

\section{Kesimpulan}

Berdasarkan hasil analisis yang telah dibahas pada bab sebelumnya, dapat diberikan simpulan sebagai berikut:

1. Hasil penelitian menunjukkan bahwa pertumbuhan perusahaan secara parsial berpengaruh negatif dan signifikan terhadap nilai perusahaan. Hal ini dibuktikan dengan menggunakan uji $\mathrm{t}$ yang menghasilkan nilai koefisien regresi sebesar $-3,799$ dengan tingkat signifikansi sebesar 0,03 .

2. Dilihat dari nilai adjusted $\mathrm{R}$ pertumbuhan perusahaan terhadap nilai perusahaan sebesar 0,770 atau $77,0 \%$. Sedangkan $23,0 \%$ sisanya dipengaruhi atau dijelaskan oleh variabel lain yang tidak dimasukkan dalam penelitian ini.

\section{Saran}

Saran yang dapat diberikan dalam penelitian ini adalah sebagai berikut:
1. Nilai perusahaan dapat menggambarkan kinerja suatu perusahaan. Oleh karena itu, bagi investor yang berinvestasi pada perusahaan outomotive sebaiknya memperhatikan variabel pertumbuhan perusahaan sebagai bahan pertimbangan dalam pengambilan keputusan investasi yang tepat dan menguntungkan nantinya. Hal ini dikarenakan variabelvariabel tersebut memberikan gambaran terhadap nilai perusahaan automotive.

2. Melakukan perluasan penelitian. Perluasan penelitian yang dimaksud adalah tidak hanya terbatas pada faktorfaktor di dalam laporan keuangan saja, tetapi juga faktor-faktor ekonomi makro seperti tingkat inflasi, pertumbuhan ekonomi, tingkat suku bunga, dan lainlain yang belum dipertimbangkan dalam penelitian ini. Selain itu juga perlu untuk menambah jumlah rasio keuangan yang diteliti.

\section{DAFTAR PUSTAKA}

Arikunto, S. 2002. Prosedur Penelitian Suatu Pendekatan Praktek, Edisi Revisi, Jakarta: Rineka Cipta.

Aries, Heru Prasetyo. 2011. Evaluasi Perusahaan. Jakarta: PPM.

Damodaran, Aswath. 2002. Investment Valuation, Tools, and Technic For Determining The Value of Any Asset. Singapore: John Willey \& Sons, Inc.

Environment and Valuation. Journal of Finance, 60, 1461-1493. Fakhruddin, $M$ dan Hadianto M. 2001. Perangkat dan Model Analisis. Investasidi Pasar Modal. Jakarta: Gramedia.

Euis dan Taswan. 2002. Pengaruh

Kebijakan Hutang Terhadap

Nilai Perusahaan Serta

Beberapa Faktor Yang

Mempengaruhinya. Jurnal

Bisnis dan Ekonomi.

Fakhruddin, M dan Hadianto M. 2001. Perangkat dan Model Analisis. Investasi di Pasar Modal. Jakarta: Gramedia. 
Ghozali, I. 2011. Aplikasi Analisis Multivariate dengan Program SPSS. Semarang: Badan Penerbit UNDIP.

Hardiningsih, Pancawati. 2009. Determinan Nilai Perusahaan. Jurnal Akuntansi Indonesia, Vol.5, No.2.

Husnan, Suad dan Pudjiastuti, Eny. 2006. Dasar-Dasar Manajemen Keuangan, Edisi 5, Yogyakarta: UPP STIM YKPN.

Machfoed, M. 1996. Akuntansi Manajemen Perencanaan dan Pembuatan Keputusan Jangka Pendek, Edisi Kelima, Buku 1, Yogyakarta: STIE Widya Wiwaha.

Mamduh M Hanafi dan Abdul Halim. 2007. Analisis Laporan

Keuangan. Yogyakarta: UPP STIE YKPN.

Mardiyati U, Ahmad Gatot N dan Putri R. 2012. Pengaruh Kebijakan Dividen, Kebijakan Hutang dan Profitabilitas terhadap Nilai Perusahaan

Saputri Dewi PY, Yuniarta GA dan Tungga Atmadja AW. 2014. Pengaruh Struktur Modal, Pertumbuhan Perusahaan dan Profitabilitas terhadap Nilai Perusahaan pada Perusahaan LQ 45 di BEI Periode 2008-2012. E-Journal S1 Ak Univ. Pendidikan Ganesha Vol.2 No.1.

Sartono, Agus. 2001. Manajemen Keuangan : Teori \& Aplikasi. Yogyakarta: BPFE.

Soliha dan Taswan. 2002. Pengaruh Kebijakan Hutang Terhadap Nilai Perusahaan Serta Beberapa Faktor yang Memengaruhi nya. Jurnal Ekonomi dan Bisnis, Vol.1., No.1. STIE STIKUBANK Semarang.

Subekti, Imam dan Indra Wijaya Kusuma, 2001, Asosiasi antara set kesempatan Investasi dengan
Pendanaan dan Dividen Perusahaan serta Implikasinya Pada Perubahan Harga Saham, Jurnal Riset Akuntansi Indonesia, vol 4, no.1.

Sugiyono. 2009. Metode Penelitian Bisnis. Bandung: CV. Alfabeta.

Suharli, Michell. 2006. Studi Empiris Terhadap Faktor yang Memengaruhi Nilai Perusahaan pada Perusahaan Go Public di Indonesia. Jurnal Manjemen Akuntansi, Vol. 6 No. 1.

Sujoko dan Soebiantoro, Ugy. 2007. Pengaruh Struktur Kepemilikan Saham,Leverage, Faktor Intern Dan Faktor Ekstern Terhadap Nilai Perusahaan, Jurnal Manajemen dan Kewirausahaan, Vol. 9 No. 1.

Tajuddin, Malik. 2013. Manajemen Keuangan Jilid 1, Makassar, STIM LPI

Taswan. 2002. Pengaruh Kebijakan Hutang Terhadap Nilai Perusahaan Serta Beberapa Faktor yang Memengaruhi nya. Jurnal Ekonomi dan Bisnis, Vol.1., No.1. STIE STIKUBANK Semarang. 